\title{
Ondansetron treatment in a child presenting with chronic intractable pruritus
}

\author{
Chantal Frigon MD MSc FRCPC, Joëlle Desparmet MD
}

C Frigon, J Desparmet. Ondansetron treatment in a child presenting with chronic intractable pruritus. Pain Res Manage 2006;11(4):245-247.

\begin{abstract}
The case of a seven-year-old boy with chronic pruritus secondary to a giant congenital melanocytic nevus is presented. The pruritus did not respond to conventional antipruritic drug treatment, but responded to ondansetron, a selective antagonist of 5-hydroxytryptamine type 3 receptors.
\end{abstract}

Key Words: Children; Giant congenital melanocytic nevus; Ondansetron; Pruritus; Serotonin antagonist

\section{Un traitement à l'ondansétron pour un enfant atteint d'un prurit chronique réfractaire}

\begin{abstract}
Est présenté le cas d'un garçon de sept ans atteint d'un prurit chronique secondaire à un naevus mélanocytique géant congénital. Le prurit n'a pas répondu à un traitement classique aux antipruritiques, mais a répondu à l'ondansétron, un antagoniste sélectif des récepteurs 5-hydroxytryptamine de type 3 .
\end{abstract}

$\mathrm{O}$ ndansetron is effective against chemotherapy-induced and postoperative nausea and vomiting $(1,2)$. Over the past few years, several publications reported on the efficacy of ondansetron in treating neuraxial opioid-induced pruritus (3-5) and uremic pruritus in continuous ambulatory peritoneal dialysis (6). The current report presents a case of a child suffering from chronic pruritus refractory to conventional antipruritic drugs who was successfully treated with ondansetron.

\section{CASE PRESENTATION}

A seven-year-old African-American boy weighing $21 \mathrm{~kg}$ was referred to the Chronic Pain Clinic at The Montreal Children's Hospital (Montreal, Quebec) with a history of disabling pruritus that was not responding to conventional treatment. The boy was born with a giant congenital melanocytic nevus with a bathing trunk distribution. The nevus was thick and was distributed from the mid-back to the buttocks with extension to the scrotum. The child had previously undergone several partial excisions of the nevus with skin grafts. Biopsies were regularly performed to evaluate the potential for malignancy. Multiple satellite nevi, that increased in number each year, covered his whole body including his face and scalp. In addition, he had three melanin-containing lesions in the brain. The brain lesions were stable and did not increase with time. The child also suffered from chronic constipation secondary to his bathing trunk nevus for which he was treated with lactulose, a colon lavage preparation (GoLYTELY, Braintree Laboratories Inc, Canada) and a high fibre diet.

The patient had suffered from generalized pruritus and scratching since his first year of life. Different antipruritic treatments were tried over the years but with poor success. He was initially treated with antihistamines - hydroxyzine and diphenhydramine. Methotrimeprazine (Nozinan, sanofi aventis Canada Inc), a neuroleptic, was added to diphenhydramine for one year. Doxepin (Sinequan, ERFA Canada Inc), an antidepressant with antihistaminic properties, and ketotifen (Zaditen, PendoPharm, Canada), a noncompetitive inhibitor of histamine type $1\left(\mathrm{H}_{1}\right)$ receptors, also failed in relieving the pruritus. The pruritus did not improve with the application of local moisturizers and a topical antipruritic (Sarna P lotion, Stiefel Canada Inc). The intensity of the pruritus seemed to increase as more nevi appeared on the boy's skin every year. On presentation, the child was suffering from severe pruritus that was affecting every aspect of his life. It prevented him from playing and concentrating at school, and disrupted his sleep pattern by waking him up approximately four to five times per night. Several times a day, he had episodes of more intense pruritus where he would become agitated and would cry while scratching himself more energetically. According to his mother, he was constantly scratching himself all over, which was also noticed during his interview. However, he only had few excoriations on his skin, probably because he was not using his nails, but the tip of his fingers and his clothes, to scratch himself. He was not anemic and did not suffer from renal, hepatic or endocrinal disease.

The boy was started on ondansetron, a selective antagonist of 5-hydroxytryptamine type $3\left(5-\mathrm{HT}_{3}\right)$ receptors, $3.2 \mathrm{mg}$ ( $5 \mathrm{~mL}=4 \mathrm{mg}$ ) taken orally, three times a day. At follow-up two weeks later, the patient and his mother reported a notable improvement. He did not complain of pruritus, was scratching himself much less and was waking up once or twice a night as opposed to four or five times a night. He was calm during the interview and did not scratch himself as he had done during his initial visit. However, the pruritus relapsed when the dose of ondansetron was lowered to $2 \mathrm{mg}$ $(2.5 \mathrm{~mL})$ orally, three times a day. Thus, the ondansetron was increased to its initial dose. Six months after initiating the treatment, the pruritus was still under control. Shortly after starting ondansetron treatment, the boy was diagnosed with metastatic malignant melanoma. Interferon alpha-2b was 
started for a total duration of 52 weeks, two months after ondansetron was initiated.

\section{DISCUSSION}

We report a case of chronic pruritus refractory to oral antihistamines $\left(\mathrm{H}_{1}\right.$ receptors $)$, topical antipruritic lotion, as well as psychotropic agents, which responded to a selective antagonist of $5-\mathrm{HT}_{3}$ receptors. Pruritus can be very disabling and, in the present case, was severely affecting the quality of life of the young boy before the introduction of ondansetron. It is unclear why the patient experienced more intense pruritus with time; however, it is likely that central sensitization for pruritus occurred (7). On the other hand, it is also possible that the constant increase of satellite nevi and the recent development of a metastatic malignant melanoma contributed to the increase in pruritus (8).

A similar case to the present report was published by Feng et al (9), concerning a three-year-old child. The seven-yearold boy in our study was started on ondansetron $3.2 \mathrm{mg}$ orally, three times a day $(0.46 \mathrm{mg} / \mathrm{kg} /$ day $)$. We were able to show a dose-response with ondansetron because pruritus relapsed when we attempted to lower the dose of ondansetron to $2 \mathrm{mg}$ orally, three times a day $(0.29 \mathrm{mg} / \mathrm{kg} / \mathrm{day})$. The child did not develop side effects with this ondansetron regimen (no headaches, his constipation was not aggravated and his alanine aminotransferase and aspartate aminotransferase levels remained normal). The pruritus was still responding to the treatment after six months.

Pruritus is transmitted by a specific neuronal pathway, which is different from the pain-processing pathway. A subset of afferent unmyelinated C-fibres innervating the skin called mechanoinsensitive and histamine-release nerve fibres transmit itch $(10,11)$. Itch impulses are transmitted from the ipsilateral dorsal horn of the spinal cord through these itch-specific C-fibres to synapse with itch-specific secondary neurons. The secondary neurons travel within the opposite anterolateral spinothalamic tract to the thalamus before reaching the somatosensory cortex (12). Free nerve endings of cutaneous sensory C-fibres serve as receptors for pruritus (known as pruriceptors) (13). Histamine stimulates $\mathrm{H}_{1}$ receptors on the itch-specific C-fibres (10). This explains how antihistamines relieve pruritus caused by different conditions such as urticaria and allergic skin reactions. However, several other types of pruritus do not respond to antihistamines, likely because substances other than histamines serve as mediators that can stimulate the itch-specific C-fibres to induce pruritus. Serotonin, acetylcholine, bradykinin, prostaglandins, leukotrienes, enzymes (tryptases and certain proteases), cannabinoids and cytokines are all pruritogenic mediators (13).

Being a selective antagonist of the serotonin $5-\mathrm{HT}_{3}$ receptors, ondansetron is effective in the treatment of certain types of pruritus which involve serotonin-related mechanism. Ondansetron has been shown to be effective for the treatment of certain cases of uremic pruritus $(6,14)$, but this finding has been refuted by another study (15). Some studies showed that neuraxial opioid-induced pruritus respond to prophylaxis $(3,16,17)$ and treatment $(5,18)$ with ondansetron. Other studies, however, concluded that ondansetron was not effective in this context (19-21). Ondansetron seems to be more effective in preventing pruritus induced by morphine than other more potent opioids such as fentanyl and sufentanil.
The itch-specific neuronal system, described above in normal subjects, is altered in patients with chronic pruritus. Schmelz et al (22) reported pathological changes in mechanoinsensitive fibres (itch-specific C-fibres) innervating symptomatic skin in a patient with chronic pruritus. They found that these fibres, which are normally devoid of spontaneous activity, had abnormal ongoing activity. They also found that the ratio of mechanoresponsive to mechanoinsensitive fibres was lower in the patient with chronic pruritus (9:16) than in normal subjects $(6: 1)$. The authors explained this difference by stating the fact that extensive scratching destroys superficial endings of mechanoresponsive fibres and induces local inflammation that may also contribute to change $\mathrm{C}$-fibre responsiveness. Ongoing activity of itch-specific C-fibres can induce central sensitization by inducing a spinal hypersensitivity for itch in patients with chronic pruritus (23). Central sensitization for itch is similar to sensitization for pain, even if their respective impulses are transmitted through different $\mathrm{C}$-fibres (24).

\section{CONCLUSION}

Mediators other than histamines are likely to be involved in our patient because he did not respond to antihistamines. Serotonin was certainly involved because the pruritus responded to ondansetron, a selective antagonist of $5-\mathrm{HT}_{3}$ receptors. Several studies $(25-27)$ reported on the safe use of ondansetron in children receiving chemotherapy for the prophylaxis of nausea and vomiting. The fact that the pruritus did not completely disappear in our patient following treatment with ondansetron suggests that other pruritogenic mediators are involved and/or that central sensitization involving ongoing activity of pruriceptors and modification of the central processing of pruritus should be treated with centrally acting drugs and not be restricted to the inhibition of pruritogens (23). Increasing knowledge in itch mechanism will hopefully lead to the development of new therapies to treat disabling pruritus.

\section{REFERENCES}

1. Koeller JM, Aapro MS, Gralla RJ, et al. Antiemetic guidelines: Creating a more practical treatment approach. Support Care Cancer 2002;10:519-22.

2. Gan TJ, Meyer T, Apfel CC, et al; Department of Anesthesiology, Duke University Medical Center. Consensus guidelines for managing postoperative nausea and vomiting. Anesth Analg 2003;97:62-71.

3. Tzeng JI, Chu KS, Ho ST, Cheng KI, Liu KS, Wang JJ. Prophylactic iv ondansetron reduces nausea, vomiting and pruritus following epidural morphine for postoperative pain control. Can J Anaesth 2003;50:1023-6.

4. Charuluxananan S, Kyokong O, Somboonviboon W, Narasethakamol A, Promlok P. Nalbuphine versus ondansetron for prevention of intrathecal morphine-induced pruritus after cesarean delivery. Anesth Analg 2003;96:1789-93.

5. Borgeat A, Stirnemann HR. Ondansetron is effective to treat spinal or epidural morphine-induced pruritus. Anesthesiology 1999;90:432-6.

6. Balaskas EV, Bamihas GI, Karamouzis M, Voyiatzis G, Tourkantonis A. Histamine and serotonin in uremic pruritus: Effect of ondansetron in CAPD-pruritic patients. Nephron 1998;78:395-402.

7. Atanassoff PG, Brull SJ, Zhang J, Greenquist K, Silverman DG, Lamotte RH. Enhancement of experimental pruritus and mechanically evoked dysesthesiae with local anesthesia. Somatosens Mot Res 1999;16:291-8. 
8. Jafarian F, Powell J, Kokta V, et al. Malignant melanoma in childhood and adolescence: Report of 13 cases. J Am Acad Dermatol 2005;53:816-822.

9. Feng J, Sethi A, Reyes-Mugica M, Antaya R. Life-threatening blood loss from scratching provoked by pruritus in the bulky perineal nevocytoma variant of giant congenital melanocytic nevus in a child. J Am Acad Dermatol 2005;53(2 Suppl 1):S139-42.

10. Schmelz M, Schmidt R, Bickel A, Handwerker HO, Torebjork HE. Specific C-receptors for itch in human skin. J Neurosci 1997;17:8003-8.

11. Andrew D, Craig AD. Spinothalamic lamina I neurons selectively sensitive to histamine: A central neural pathway for itch. Nat Neurosci 2001;4:72-7.

12. Krajnik M, Zylicz Z. Understanding pruritus in systemic disease. J Pain Symptom Manage 2001;21:151-68.

13. Stander S, Steinhoff M, Schmelz M, Weisshaar E, Metze D, Luger T. Neurophysiology of pruritus: Cutaneous elicitation of itch. Arch Dermatol 2003;139:1463-70.

14. Deshpande PV. Ondansetron for paediatric uraemic pruritus: A case report. Pediatr Nephrol 2004;19:694-6

15. Murphy M, Reaich D, Pai P, Finn P, Carmichael AJ. A randomized, placebo-controlled, double-blind trial of ondansetron in renal itch. Br J Dermatol 2003;148:314-7.

16. Gurkan Y, Toker K. Prophylactic ondansetron reduces the incidence of intrathecal fentanyl-induced pruritus. Anesth Analg 2002;95:1763-6

17. Yeh HM, Chen LK, Lin CJ, et al. Prophylactic intravenous ondansetron reduces the incidence of intrathecal morphine-induced pruritus in patients undergoing cesarean delivery. Anesth Analg 2000;91:172-5.

18. Charuluxananan S, Somboonviboon W, Kyokong O, Nimcharoendee K. Ondansetron for treatment of intrathecal morphine-induced pruritus after cesarean delivery. Reg Anesth Pain Med 2000;25:535-9.

19. Waxler B, Mondragon SA, Patel SN, Nedumgottil K. Prophylactic ondansetron does not reduce the incidence of itching induced by intrathecal sufentanil. Can J Anaesth 2004;51:685-9.

20. Wells J, Paech MJ, Evans SF. Intrathecal fentanyl-induced pruritus during labour: The effect of prophylactic ondansetron. Int J Obstet Anesth 2004;13:35-9.

21. Yazigi A, Chalhoub V, Madi-Jebara S, Haddad F, Hayek G. Prophylactic ondansetron is effective in the treatment of nausea and vomiting but not on pruritus after cesarean delivery with intrathecal sufentanil-morphine. J Clin Anesth 2002;14:183-6.

22. Schmelz M, Hilliges M, Schmidt R, et al. Active "itch fibers" in chronic pruritus. Neurology 2003;61:564-6.

23. Ikoma A, Rukwied R, Stander S, Steinhoff M, Miyachi Y, Schmelz M. Neurophysiology of pruritus: Interaction of itch and pain. Arch Dermatol 2003;139:1475-8.

24. Andrew D, Schmelz M, Ballantyne JC. Itch: Mechanisms and mediators. In: Dostrovsky JO, Carr DB, Koltzenburg M, eds. Progress in Pain Research and Management. Seattle: IASP Press, 2003:213-226

25. Goodin S, Cunningham R. 5-HT(3)-receptor antagonists for the treatment of nausea and vomiting: A reappraisal of their side-effect profile. Oncologist 2002;7:424-36.

26. Gralla RJ, Osoba D, Kris MG, et al. Recommendations for the use of antiemetics: Evidence-based, clinical practice guidelines. American Society of Clinical Oncology. J Clin Oncol 1999;17:2971-94. (Erratum in 1999;17:3860, 2000;18:3064).

27. ASHP therapeutic guidelines on the pharmacologic management of nausea and vomiting in adult and pediatric patients receiving chemotherapy or radiation therapy or undergoing surgery. Am J Health Syst Pharm 1999;56:729-64. 


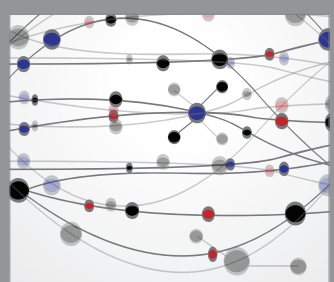

The Scientific World Journal
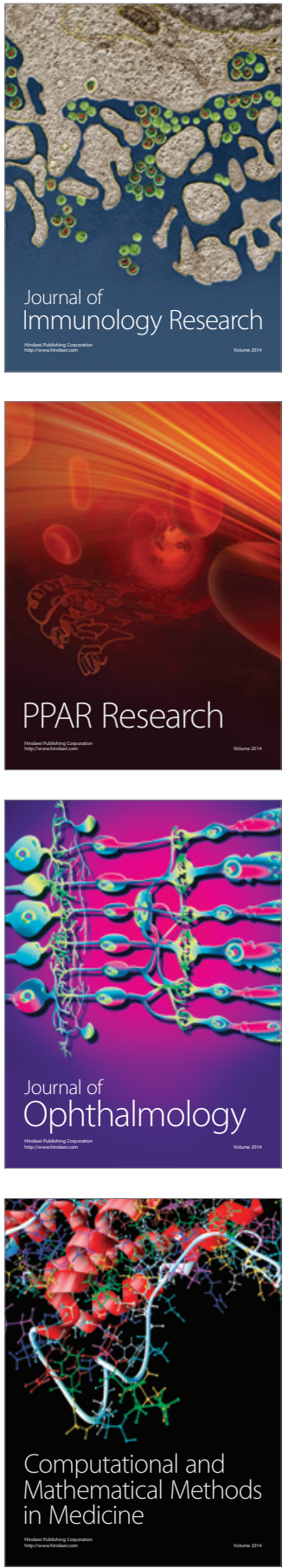

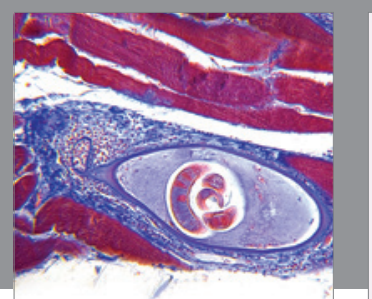

Gastroenterology Research and Practice

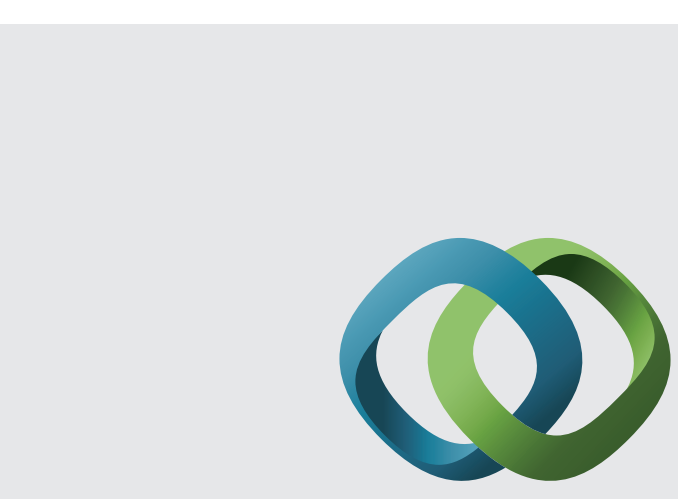

\section{Hindawi}

Submit your manuscripts at

http://www.hindawi.com
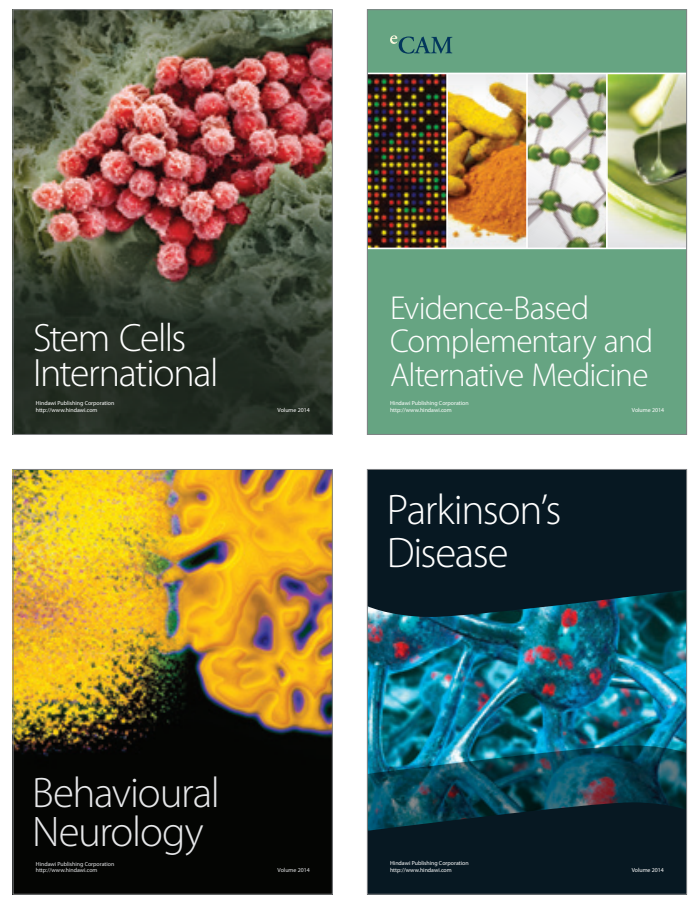
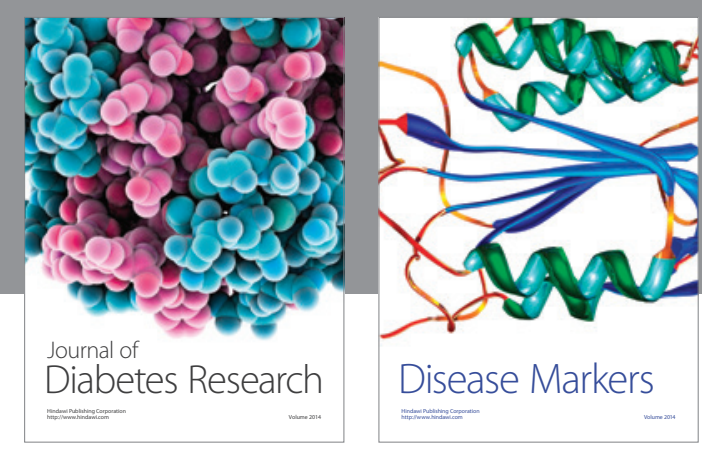

Disease Markers
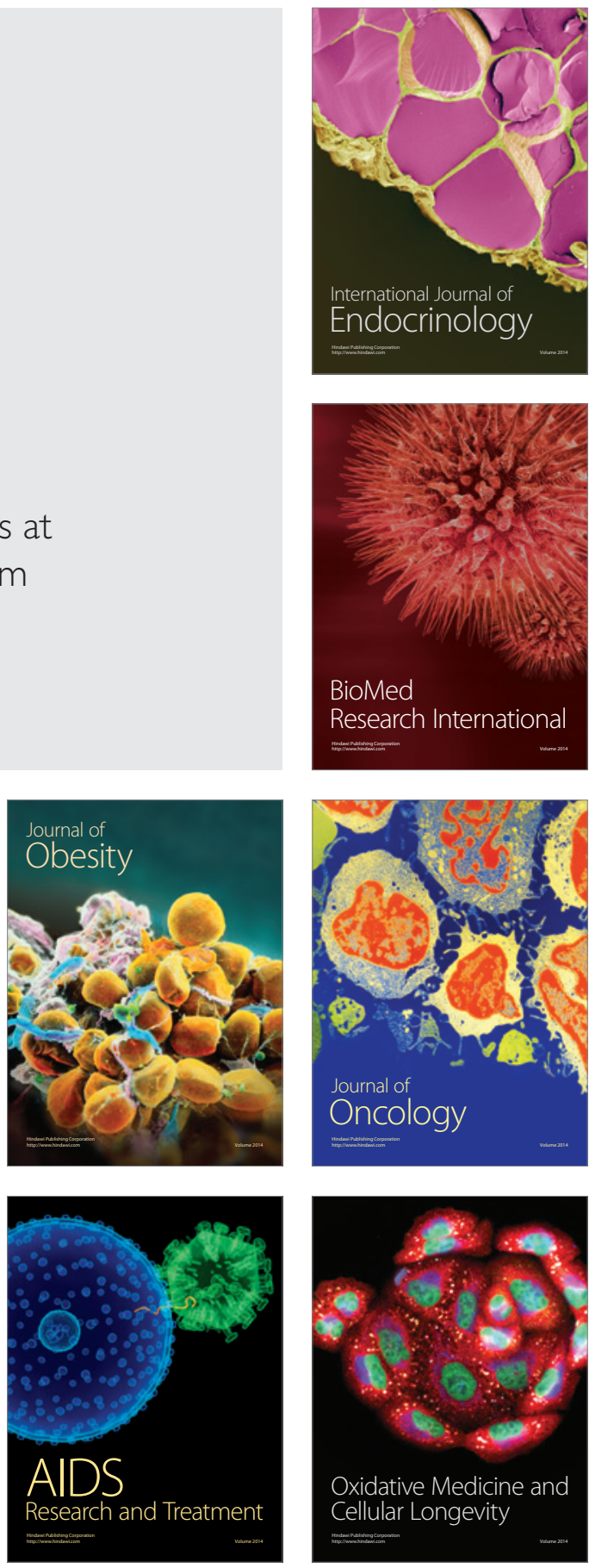